\title{
Alternative methodology for the germination test in chemically treated corn hybrid
}

\section{seeds}

\author{
Metodologia alternativa para o teste de germinação em sementes híbridas de milho tratadas \\ quimicamente
}

Metodología alternativa para la prueba de germinación en semillas de maíz híbridas tratadas químicamente

Cristina Rossetti

ORCID: https://orcid.org/0000-0003-2772-5952 Federal University of Pelotas, Brazil E-mail: cristinarosseti@yahoo.com.br

Natália Pedra Madruga

ORCID: https://orcid.org/0000-0001-9650-1069 Federal University of Pelotas, Brazil E-mail: nataliapmadruga@hotmail.com Nícolas da Conceição de Ávila ORCID: https://orcid.org/0000-0002-4440-4387 Federal University of Pelotas, Brazil E-mail: nicolasavila-@ hotmail.com Josiane Cantuária Figueiredo ORCID: https://orcid.org/0000-0001-7105-1241 Federal University of Pelotas, Brazil E-mail: josycantuaria@yahoo.com.br

Carem Rosane Coutinho Saraiva ORCID: https://orcid.org/0000-0002-0810-2402 Federal University of Pelotas, Brazil E-mail: caremsaraiva@ hotmail.com

Francine Bonemann Madruga

ORCID: https://orcid.org/0000-0001-7202-7462 Federal University of Pelotas, Brazil

E-mail: francinebonemann@hotmail.com

Isabela da Rosa Bersch

ORCID: https://orcid.org/0000-0002-6698-5362 Federal University of Pelotas, Brazil E-mail: isa1_rosa@yahoo.com.br

Letícia Barão Medeiros

ORCID: https://orcid.org/0000-0002-2862-7564 Federal University of Pelotas, Brazil E-mail: lele-medeiros@hotmail.com

Lilian Vanussa Madruga de Tunes ORCID: https://orcid.org/0000-0001-7562-1926 Federal University of Pelotas, Brazil E-mail:lilianmtunes@yahoo.com.br

\begin{abstract}
The objective of this work was to identify the most suitable conditions for the evaluation of the germination test in corn seeds through the use of different substrates. Two tests were carried out for the development of the work. In test 1, the hybrid Morgan 30A37 PWV was used in a factorial scheme of 5 substrates with 8 chemical treatments. The seeds were treated industrially with the following insecticides: Inside FS, Inside FS + Maestro FS, Maestro FS, Poncho, Inside FS + BioCoat Corn, Inside FS + Maestro FS + BioCoat Corn and Maestro FS + BioCoat Corn. For test 2, the hybrid used was the FS533 PWV in a factorial scheme of 5 substrates and 5 treatments, in which the seeds received the industrial treatment with the insecticides: Inside FS, Inside FS + Maestro FS, Maestro FS and Poncho. Both tests were submitted to two temperatures $\left(20^{\circ} \mathrm{C}\right.$ and $25^{\circ} \mathrm{C}$ ) and five substrates (germitest $₫$ paper; germitest ${ }^{\circ}$ paper + sand; germitest ${ }^{\circledR}$ paper + soil; germitest ${ }^{\circledR}$ paper + coal and brown paper). The most suitable substrates for installing the germination test in chemically treated corn seeds were brown pepper and germitest ${ }^{\circledR}+$ charcoal. And
\end{abstract}


the temperature of $20^{\circ} \mathrm{C}$ is the one that allows the most uniform and rapid development of normal seedlings in the germination test in treated hybrid corn seeds.

Keywords: Zea Mays; Seed treatment; Temperatures; Different substrates.

\section{Resumo}

O objetivo deste trabalho foi identificar quais as condições mais adequadas para avaliação do teste de germinação em sementes de milho através da utilização de diferentes substratos. Foram realizados dois ensaios para o desenvolvimento do trabalho. No ensaio 1 foi utilizado o híbrido Morgan 30A37 PWV num esquema fatorial de 5 substratos com 8 tratamentos químicos. As sementes foram tratadas industrialmente com os seguintes inseticidas: Inside FS, Inside FS + Maestro FS, Maestro FS, Poncho, Inside FS + BioCoat Corn, Inside FS + Maestro FS + BioCoat Corn e Maestro FS + BioCoat Corn. Já para o ensaio 2, o híbrido utilizado foi o FS533 PWV em um esquema fatorial de 5 substratos e 5 tratamentos, neste as sementes receberam o tratamento industrial com os inseticidas: Inside FS, Inside FS + Maestro FS, Maestro FS e Poncho. Ambos os ensaios foram submetidos a duas temperaturas $\left(20^{\circ} \mathrm{C}\right.$ e $\left.25^{\circ} \mathrm{C}\right)$ e cinco substratos (papel germitest ${ }^{\circledR}$; papel germitest $\AA$ + areia; papel germitest ${ }^{\circledR}+$ solo; papel germitest ${ }^{\circledR}+$ carvão e papel pardo). Os substratos mais indicados para instalação do teste de germinação em sementes de milho tratadas quimicamente foram pepel pardo e germitest ${ }^{\circledR}+$ carvão. E a temperatura de $20^{\circ} \mathrm{C}$ é a que possibilita o desenvolvimento mais uniforme e rápido de plântulas normais no teste de germinação em sementes de híbrido de milho tratadas.

Palavras-chave: Zea Mays; Tratamento de sementes; Temperaturas; Diferentes substratos.

\section{Resumen}

El objetivo de este trabajo fue identificar las condiciones más adecuadas para evaluar la prueba de germinación en semillas de maíz mediante el uso de diferentes sustratos. Se realizaron dos pruebas para el desarrollo de la obra. En el ensayo 1 se utilizó el híbrido Morgan 30A37 PWV en un esquema factorial de 5 sustratos con 8 tratamientos químicos. Las semillas fueron tratadas industrialmente con los siguientes insecticidas: Inside FS, Inside FS + Maestro FS, Maestro FS, Poncho, Inside FS + BioCoat Corn, Inside FS + Maestro FS + BioCoat Corn y Maestro FS + BioCoat Corn. En cuanto al ensayo 2, el híbrido utilizado fue el FS533 PWV en un esquema factorial de 5 sustratos y 5 tratamientos, en este las semillas recibieron el tratamiento industrial con insecticidas: Inside FS, Inside FS + Maestro FS, Maestro FS y Poncho. Ambas pruebas fueron sometidas a dos temperaturas $\left(20^{\circ} \mathrm{C} \mathrm{y} 25^{\circ} \mathrm{C}\right)$ y cinco sustratos (papel germitest $\AA$; papel germitest ${ }^{\circledR}+$ arena; papel germitest ${ }^{\circledR}+$ tierra; papel germitest ${ }^{\circledR}+$ carboncillo y papel marrón). Los sustratos más adecuados para instalar la prueba de germinación en semillas de maíz tratadas químicamente fueron el pepel marrón y germitest ${ }^{\circledR}+$ carbón. Y la temperatura de $20^{\circ} \mathrm{C}$ es la que permite el desarrollo más uniforme y rápido de plántulas normales en la prueba de germinación en semillas híbridas de maíz tratadas.

Palabras clave: Zea Mays; Tratamiento de semillas; Temperaturas; Diferentes sustratos.

\section{Introduction}

Over the past few decades, corn has reached the level of the largest agricultural crop in the world, being the only one to have surpassed the 1 billion ton mark, abandoning former competitors, such as rice and wheat. Concomitantly with its importance in terms of production, culture is still notable for its diverse uses. Estimates point to more than 3.500 applications of this cereal. In addition to the relevance in terms of food safety, human and, mainly, animal feed, it is possible to produce with corn a multitude of products, such as fuels, beverages, polymers etc. (Miranda, 2018).

The seed for being one of the main inputs of agriculture and its quality is one of the primary factors for the establishment of any crop (Nunes; Menezes; Cargnelutti Filho, 2019), being influenced by different biotic and abiotic factors, such as chemical treatment and storage conditions. To maintain physiological quality, seed treatment has been used as a protection tool both in the field and in storage, being a valuable measure to control and / or prevent the attack of pests and pathogens. The lack of this initial protection can have a direct impact on productivity.

Crops with low population density (number of plants per area), such as corn, can suffer severe damage due to the attack of pests in the germination and seedling phases and result in a reduction in the productive potential of crops. Thus, the use of seed treatment with insecticides has become an important protection strategy in these phases, ensuring the uniform establishment of plant populations in the field (Gallo et al., 2018). 
For both untreated and treated seeds, the standardized quality test required by the Ministry of Agriculture, Livestock and Supply (MAPA) for the seed trade is that of germination. However, the germination test is performed under ideal conditions of humidity, temperature, substrate, light and oxygen, a fact that does not match the reality of the field. It is a standardized test, as it has a wide possibility of repetition of results, within reasonable levels of tolerance, if the instructions established in the National Seed Analysis Rules (Brasil, 2009) such as international ones, such as ISTA and AOSA.

In the standard germination test for corn, the use of substrates such as germination paper or sand is recommended (Brasil, 1992). These substrates have great influence, because according to the type of material used, factors such as structure, aeration, water holding capacity and degree of infestation of pathogens, can vary from one to the other. Thus, there may be differences between the results, if there is no standardization of the methodology in relation to the substrate, considering the level of vigor of the seed and the presence of some chemical treatment.

In this context, the present work aimed to identify which conditions are suitable for the evaluation of germination in corn seeds chemically treated through the use of different substrates.

\section{Methodology}

The present work was carried out at the Didactic Laboratory of Seed Analysis "Flavio Rocha" of the Federal University of Pelotas, located in the city of Pelotas in the state of Rio Grande do Sul.

Statistical analysis: Conducted using a completely randomized design. For test 1, a 5x8 factorial scheme (five substrates and eight treatments) was used, in which the hybrid 30A37 PWV was worked. For trial 2, the factorial scheme was 5x5 (five substrates and five treatments) and the hybrid used was the FS533 PWV. The sum of the two trials totaled 13 chemical treatments. The averages obtained were subjected to analysis of variance (Machado; Conceição, 2005) and the statistical analysis was performed with the aid of the WinStat statistical package, the averages test was performed by the Tukey test, at the level of $5 \%$ of significance $(\mathrm{p} \leq 0,05)$.

Tests and treatments performed: The evaluations performed in the laboratory were the same for both tests and are described below:

Chemical Treatments (TSI): The corn seeds were treated industrially with insecticides as described in tables 1 and 2 . INSIDE FS and Poncho® insecticides are systemic insecticides of the specific neonicotinoid chemical group for seed treatment, while MAESTRO FS is a Fipronil insecticide.

The treatments were submitted to two temperatures $\left(20^{\circ} \mathrm{C}\right.$ and $\left.25^{\circ} \mathrm{C}\right)$ and five substrates (germitest ${ }^{\circledR}$ paper; germitest ${ }^{\circledR}$ paper + sand; germitest ${ }^{\circledR}$ paper + soil; germitest ${ }^{\circledR}$ paper + coal and brown paper). The total amount of seeds per treatment was 200 distributed in four subsamples of 50 seeds.

To the treatments that include sand and soil, $17 \mathrm{~g}$ of these materials were added homogeneously on the substrate paper of each roll for each treatment. The treatment carried out with germitest ${ }^{\circledR}$ paper + charcoal was added $10 \mathrm{~g}$ of the material, homogeneously on the substrate paper of each roll for each treatment. In both treatments mentioned above, only the germitest ${ }^{\circledR}$ paper was moistened, with distilled water in the proportion of 3 times the weight of the paper. 
Table 1. Commercial products, doses and volumes of final syrup for each seed treatment in the cultivation of the hybrid corn Morgan 30A37 used for the test 1. FAEM/UFPel. Capão do Leão, RS, 2020.

\begin{tabular}{|c|c|c|c|c|c|}
\hline Treatment & $\begin{array}{l}\text { Business } \\
\text { Name }^{1}\end{array}$ & Active ingredient & Product type & $\begin{array}{c}\text { Commercial } \\
\text { Product } \\
\text { Dose }\end{array}$ & $\begin{array}{c}\text { Dose }(m L / 100 \\
k g \text { de seeds })\end{array}$ \\
\hline 1 & Witness & - & - & - & - \\
\hline 2 & Inside FS & CLOTIANIDINA & Insecticide & 600 g.i.a/L & $70 \mathrm{ml}$ \\
\hline 3 & $\begin{array}{l}\text { Inside FS + } \\
\text { Maestro FS }\end{array}$ & $\begin{array}{l}\text { CLOTIANIDINA } \\
+ \text { FIPRONIL }\end{array}$ & Insecticide & $\begin{array}{l}600 \text { g.i.a/L+ } \\
250 \text { g.i.a/L }\end{array}$ & $70 \mathrm{ml}+50 \mathrm{ml}$ \\
\hline 4 & Maestro FS & FIPRONIL & Insecticide & 250 g.i.a/L & $50 \mathrm{ml}$ \\
\hline 5 & Poncho & CLOTIANIDINA & Insecticide & 600 g.i.a/L & $70 \mathrm{ml}$ \\
\hline 6 & $\begin{array}{c}\text { Inside FS + } \\
\text { BioCoat Corn }\end{array}$ & $\begin{array}{l}\text { CLOTIANIDINA } \\
\text { + POLÍMERO* }\end{array}$ & Insecticide & 600 g.i.a/L & $70 \mathrm{ml}$ \\
\hline 7 & $\begin{array}{l}\text { Inside FS + } \\
\text { Maestro FS + } \\
\text { BioCoat Corn }\end{array}$ & $\begin{array}{c}\text { CLOTIANIDINA } \\
+ \text { FIPRONIL + } \\
\text { POLÍMERO* }\end{array}$ & Insecticide & $\begin{array}{l}600 \text { g.i.a/L+ } \\
250 \text { g.i.a/L }\end{array}$ & $70 \mathrm{ml}+50 \mathrm{ml}$ \\
\hline 8 & $\begin{array}{l}\text { Maestro FS + } \\
\text { BioCoat Corn }\end{array}$ & $\begin{array}{l}\text { FIPRONIL+ } \\
\text { POLÍMERO* }\end{array}$ & Insecticide & 250 g.i.a/L & $50 \mathrm{ml}$ \\
\hline
\end{tabular}

1 Trade name: * mL.60,000-1 seeds * 400ml / 100Kg seeds. Source: Authors.

Table 2. Commercial products, doses and volumes of final syrup for each seed treatment in the hybrid corn crop FS533 PWV, used for test 2. FAEM/UFPel. Capão do Leão, RS, 2020.

\begin{tabular}{cccccc}
\hline \hline Treatment & $\begin{array}{c}\text { Business } \\
\text { Name }\end{array}$ & Active ingredient & Product type & $\begin{array}{c}\text { Commercial } \\
\text { Product } \\
\text { Dose }\end{array}$ & $\begin{array}{c}\text { Dose }(\mathrm{mL} / 100 \\
\text { kg de seeds) }\end{array}$ \\
\hline \hline 9 & Witness & - & - & - & - \\
10 & Inside FS & CLOTIANIDINA & Insecticide & $600 \mathrm{~g} . \mathrm{i} . \mathrm{a} / \mathrm{L}$ & $70 \mathrm{ml}$ \\
11 & Inside FS + & CLOTIANIDINA & Insecticide & $600 \mathrm{~g} . \mathrm{i} . \mathrm{a} / \mathrm{L}+$ & $70 \mathrm{ml}+50 \mathrm{ml}$ \\
12 & Maestro FS & + FIPRONIL & & $250 \mathrm{~g} . \mathrm{i} . \mathrm{a} / \mathrm{L}$ & \\
13 & Maestro FS & FIPRONIL & Insecticide & $250 \mathrm{~g} . \mathrm{i} . \mathrm{a} / \mathrm{L}$ & $50 \mathrm{ml}$ \\
\hline \hline
\end{tabular}

TTrade name: * mL.60,000-1 seeds.

Source: Authors.

Germination Test: Performed using four repetitions of each treatment, containing four subsamples of 50 seeds, sown in moistened germitest ${ }^{\circledR}$ paper rolls, with distilled water in the proportion of 3 times the weight of the paper. The rolls were placed in germinators at temperatures of $2{ }^{\circ} \mathrm{C}$ and $25^{\circ} \mathrm{C}$. The germination evaluation was carried out at 4 days, in which the percentage of normal, abnormal seedlings and non-germinated seeds (hard, dormant or dead) was determined, obtaining the germination result according to the Rules for Seed Analysis (Brasil, 2009).

The soil used in the test is a Planossolo Háplico Eutrófico solódico, for its use in the germination test, it was subjected to two passages in sieves with a $2 \mathrm{~mm}$ mesh opening for breaking clods and removing unsuitable debris. While the occupied sand once passed through the $2 \mathrm{~mm}$ mesh sieve to remove the larger debris. Both the soil and the sand come from the Centro Agropecuário da Palma located on the banks of the BR 116 near Pelotas-RS.

The coal was obtained from the burning of wood from Eucalyptus benthamii eucalyptus trees, the acquisition was made in a Supermarket chain. For use in the test, it went through the grinding process in an industrial seed crusher with a mesh 
opening of 210 micrometers. This process was carried out at the Didactic Laboratory of Seed Analysis in the UFPel Phytotechnics department.

For brown paper, 50 seeds per roll were used, moistened with distilled water in a proportion of 3.5 times the weight of the paper. The rolls were placed in germinators at temperatures of 20 and $25^{\circ} \mathrm{C}$. The germination evaluation was carried out at 4 days, in which the percentage of normal, abnormal seedlings and non-germinated seeds (hard, dormant or dead) was determined, obtaining the germination result according to the Rules for Seed Analysis (Brasil, 2009).

For all substrates, after assembling the rolls, they were packed in a plastic bag so that the humidity of the samples was maintained and then sent to the germinators at the appropriate temperatures.

Emergency Test: Performed by sowing 50 seeds per repetition, thus totaling 200 seeds per treatment, which are handled in trays containing soil substrate and sand substrate. The evaluation was carried out in a count at 14 days after sowing, determining the number of normal seedlings and expressing the results as a percentage.

The soil used in the test is a Planossolo Háplico Eutrófico solódico from the Centro Agropecuário da Palma located on the banks of the BR 116 near Pelotas-RS. For use it was sieved through $2 \mathrm{~mm}$ sieves. The sand used in the test also comes from the Centro Agropecuário da Palma, since it had a particle size of approximately $2.4 \mathrm{~mm}$, only impurities such as leaves, and clods were removed manually.

\section{Results and Discussion}

The germination test for corn seeds (Zea mays, L.) standardized in the Seed Analysis Rules (Brasil, 2009) indicates the use of paper roll substrate (RP) or between sand (EA), submitted to constant temperatures of $20^{\circ} \mathrm{C}, 25^{\circ} \mathrm{C}$ or $30^{\circ} \mathrm{C}$ and/or alternating temperature of $20-30^{\circ} \mathrm{C}$.

It was observed for the two corn hybrids tested in the work in general, a variable performance, regarding germination (tables 3,4,5 and 6), in different temperatures, substrates and chemical treatment performed.

It is observed for the Morgan Hybrid 30A37PW when at a temperature of $25^{\circ} \mathrm{C}$ (Table 3), that treatment 2, where the TSI was performed with the insecticide Inside FS, from the substrate germitest ${ }^{\circledR}$ (control) shows less germination potential when compared to treatment 4, to which the TSI was performed with the insecticide Maestro FS. The negative effect of Inside FS on germitest ${ }^{\circledR}$ paper may be associated with a phytotoxic effect, a higher concentration of product around the seeds in the germination test compared to other substrates with a larger contact surface, due to the addition of sand, coal, soil or even the distinct chemical characteristics present in brown paper. 
Table 3: Result of the germination test of the Morgan Hybrid 30A37PW at a temperature of $25^{\circ} \mathrm{C}$, comparing different substrates: germitest ${ }^{\circledR}$; germitest ${ }^{\circledR}+$ sand; germitest ${ }^{\circledR}+$ coal; germitest ${ }^{\circledR}+$ soil and brown paper under different chemical treatments: treatment 1 (witness), treatment 2 (Inside FS), treatment 3 (Inside FS + Maestro FS), treatment 4 (Maestro FS), treatment 5 (Poncho), treatment 6 (Inside FS + BioCoat Corn), treatment 7 (Inside FS + Maestro FS + BioCoat Corn), treatment 8 (Maestro FS + BioCoat Corn). FAEM/UFPel. Capão do Leão, RS, 2020.

\begin{tabular}{cccccc}
\hline \hline & \multicolumn{5}{c}{ SUBSTRATES } \\
\cline { 2 - 6 } TREATMENTS & $\begin{array}{c}\text { Germitest } \\
\text { (Witness) }\end{array}$ & Sand & Coal & Ground & Brown Paper \\
\hline \hline 1 & $85 \mathrm{~b}$ & $95 \mathrm{a}$ & $91 \mathrm{ab}$ & $91 \mathrm{a}$ & $93 \mathrm{a}$ \\
2 & $79 \mathrm{~b}$ & $93 \mathrm{a}$ & $96 \mathrm{a}$ & $94 \mathrm{a}$ & $96 \mathrm{a}$ \\
3 & $82 \mathrm{~b}$ & $86 \mathrm{~b}$ & $96 \mathrm{a}$ & $92 \mathrm{a}$ & $93 \mathrm{a}$ \\
4 & $85 \mathrm{~b}$ & $97 \mathrm{a}$ & $93 \mathrm{a}$ & $93 \mathrm{a}$ & $95 \mathrm{a}$ \\
5 & $81 \mathrm{~b}$ & $95 \mathrm{a}$ & $97 \mathrm{a}$ & $95 \mathrm{a}$ & $92 \mathrm{a}$ \\
6 & $90 \mathrm{a}$ & $96 \mathrm{a}$ & $95 \mathrm{a}$ & $96 \mathrm{a}$ & $94 \mathrm{a}$ \\
7 & $91 \mathrm{a}$ & $98 \mathrm{a}$ & $96 \mathrm{a}$ & $95 \mathrm{a}$ & $93 \mathrm{a}$ \\
8 & $93 \mathrm{a}$ & $98 \mathrm{a}$ & $97 \mathrm{a}$ & $99 \mathrm{a}$ & $95 \mathrm{a}$ \\
\hline \hline
\end{tabular}

Means followed by the same letter in the column do not differ statistically from each other by the Tukey test for the substrates used at $5 \%$ probability.

Source: Authors.

At treatment 6 (Inside FS + BioCoat Corn), treatment 7 (Maestro FS + Inside FS + BioCoat Corn) and treatment 8 (Maestro FS + BioCoat Corn), there were no significant differences in relation to the tested substrates and the control (Table 3). This is due to the fact that both treatments obtained the use of polymer (BioCoat Corn) ensuring a homogeneous distribution, quality and adherence of the solutions used in the treatment of seeds. Among the benefits of pelliculation, there is a better retention of phytosanitary products to seeds (Maude, 2008; Sampaio \& Sampaio, 2008; Silveira, 2010; Smith, 2011), ensuring that insecticides, fungicides, among others, act where they really are needed.

For treatment 5 (Poncho®), when comparing the tested temperatures $\left(20^{\circ} \mathrm{C}\right.$ and $\left.25^{\circ} \mathrm{C}\right)$, no significant differences were observed (tables 3 and 4). The use of alternative substrates applied together with the germitest ${ }^{\circledR}$ paper or the use of brown paper allowed the seeds of the hybrid Morgan 30A37 PW to fully express its physiological potential, reducing the percentage of abnormal seedlings when confronted with the control.

The Insecticide Poncho ${ }^{\circledR}$ in which it has the active ingredient clothianidin belong to the chemical group of neonicotinoids and are substances of systemic action, this has been used frequently in the TSI in corn. The insecticide when applied to the seed can also provide physiological action on the plants, promoting more vigorous growth of the same and improving their productive potential (Castro et al., 2018).

Agrochemicals are usually evaluated for their efficiency in controlling pests and diseases, however some products can promote effects, still little known, capable of modifying plant physiology, metabolism and morphology, which will influence the growth and yield of plants. As is the case of Poncho® that has hormonal control in plants, functioning as a bioactivator (Castro, 2006).

These, in turn, are complex organic growth-modifying substances capable of acting indirectly in the synthesis of plant hormone precursors that lead to hormonal synthesis and increases in production (Castro, 2006). 
Table 4: Result of the germination test of the Morgan Hybrid 30A37PW at a temperature of $20^{\circ} \mathrm{C}$, comparing different substrates: germitest ${ }^{\circledR}$; germitest ${ }^{\circledR}+$ sand; germitest ${ }^{\circledR}+$ coal; germitest ${ }^{\circledR}+$ soil and brown paper under different chemical treatments: treatment 1 (witness), treatment 2 (Inside FS), treatment 3 (Inside FS + Maestro FS), treatment 4 (Maestro FS), treatment 5 (Poncho), treatment 6 (Inside FS + BioCoat Corn), treatment 7 (Inside FS + Maestro FS + BioCoat Corn), treatment 8 (Maestro FS + BioCoat Corn). FAEM/UFPel. Capão do Leão, RS, 2020.

\begin{tabular}{cccccc}
\hline \hline TREATMENTS & \multicolumn{5}{c}{ SUBSTRATES } \\
\cline { 2 - 6 } & $\begin{array}{c}\text { Germitest }{ }^{(\text {Witness })} \\
\text { Sand }\end{array}$ & Coal & Ground & Brown Paper \\
\hline \hline 1 & $96 \mathrm{a}$ & $97 \mathrm{a}$ & $91 \mathrm{~b}$ & $96 \mathrm{a}$ & $95 \mathrm{ab}$ \\
2 & $84 \mathrm{~b}$ & $97 \mathrm{a}$ & $96 \mathrm{a}$ & $96 \mathrm{a}$ & $95 \mathrm{a}$ \\
4 & $83 \mathrm{~b}$ & $96 \mathrm{a}$ & $96 \mathrm{a}$ & $97 \mathrm{a}$ & $97 \mathrm{a}$ \\
5 & $92 \mathrm{~b}$ & $99 \mathrm{a}$ & $98 \mathrm{ab}$ & $97 \mathrm{a}$ & $96 \mathrm{ab}$ \\
6 & $82 \mathrm{~b}$ & $96 \mathrm{a}$ & $95 \mathrm{a}$ & $94 \mathrm{a}$ & $96 \mathrm{a}$ \\
7 & $89 \mathrm{~b}$ & $97 \mathrm{a}$ & $98 \mathrm{ab}$ & $97 \mathrm{a}$ & $98 \mathrm{a}$ \\
8 & $94 \mathrm{a}$ & $97 \mathrm{a}$ & $97 \mathrm{a}$ & $97 \mathrm{a}$ & $93 \mathrm{a}$ \\
\hline \hline
\end{tabular}

Means followed by the same letter in the column do not differ statistically from each other by the Tukey test for the substrates used at $5 \%$ probability.

Source: Authors.

In the case of the hybrid FS533 PWV, the germination data are higher at a constant temperature of 20 ${ }^{\circ} \mathrm{C}$ (Table 6) compared to $25^{\circ} \mathrm{C}$ (Table 5), in all evaluations. The interaction between the initial water content of the seeds and the imbibition temperature is a determining factor for the occurrence of permanent or transient changes in the structure of cell membranes, therefore, natural or artificial mechanisms can be developed in order to prevent or minimize the imbibition damage, caused by the rapid rehydration of tissues when the seeds are placed to germinate (Costa et al. 2008).

Table 5: Result of the germination test of the Hybrid FS 533PWV at a temperature of $25^{\circ} \mathrm{C}$, comparing different substrates: germitest $\AA$; germitest $\AA$ + sand; germitest $\AA$ + coal; germitest $\AA$ + soil and brown paper under different chemical treatments: treatment 9 (witness), treatment 10 (Inside FS), treatment 11 (Inside FS + Maestro FS), treatment 12 (Maestro FS), treatment 13 (Poncho). FAEM/UFPel. Capão do Leão, RS, 2020.

\begin{tabular}{cccccc}
\hline \hline & \multicolumn{5}{c}{ SUBSTRATES } \\
\cline { 2 - 6 } TREATMENTS & $\begin{array}{c}\text { Germitest } \\
\text { (Witness) }\end{array}$ & Sand & Coal & Ground & Brown Paper \\
\hline \hline 9 & $71 \mathrm{c}$ & $78 \mathrm{bc}$ & $85 \mathrm{~b}$ & $76 \mathrm{bc}$ & $97 \mathrm{a}$ \\
10 & $69 \mathrm{~b}$ & $68 \mathrm{~b}$ & $83 \mathrm{a}$ & $84 \mathrm{a}$ & $94 \mathrm{a}$ \\
11 & $88 \mathrm{a}$ & $97 \mathrm{a}$ & $95 \mathrm{a}$ & $96 \mathrm{a}$ & $95 \mathrm{a}$ \\
12 & $93 \mathrm{a}$ & $93 \mathrm{a}$ & $94 \mathrm{a}$ & $93 \mathrm{a}$ & $94 \mathrm{a}$ \\
13 & $88 \mathrm{a}$ & $94 \mathrm{a}$ & $93 \mathrm{a}$ & $96 \mathrm{a}$ & $98 \mathrm{a}$ \\
\hline \hline
\end{tabular}

Means followed by the same letter in the column do not differ statistically from each other by the Tukey test for the substrates used at $5 \%$ probability.

Source: Authors.

For the hybrid FS 533PWV at a temperature of $25^{\circ} \mathrm{C}$ (table 5), treatment 11 (Inside FS + Maestro FS), treatment 12 (Maestro FS) and treatment 13 (Poncho), obtained superior performance when it comes to the germination test, compared to 
the control (treatment 9). Thus, confirming the importance of the TSI for the corn crop, since it allows a lower incidence of the attack of the so-called soil pests, which attack the crop at the beginning of germination and significantly affect productivity.

Menten and Morais, 2015, state that in addition to the initial protection and the direct impact on productivity, the TSI has immediate benefits, since the cost of the process is less than the gain in yield, and in the medium / long term, it provides a system of balanced production, constituting a cheap insurance.

When dealing with the temperature of $20^{\circ} \mathrm{C}$ (Table 6), only treatment 13 (Poncho), obtained significant differences when compared to the control. The fact that there was a significant difference for this treatment, shows the agronomic efficiency of the product Poncho, in the application via seed treatment.

Table 6: Result of the germination test of the Hybrid FS 533PWV at a temperature of $20^{\circ} \mathrm{C}$, comparing different substrates: germitest ${ }$; germitest ${ }^{\circledR}+$ sand; germitest ${ }^{\circledR}+$ coal; germitest ${ }^{\circledR}+$ soil and brown paper under different chemical treatments: treatment 9 (witness), treatment 10 (Inside FS), treatment 11 (Inside FS + Maestro FS), treatment 12 (Maestro FS), treatment 13 (Poncho). FAEM / UFPel. Capão do Leão, RS, 2020.

\begin{tabular}{cccccc}
\hline \multirow{2}{*}{ TREATMENTS } & \multicolumn{5}{c}{ SUBSTRATES } \\
\cline { 2 - 6 } & $\begin{array}{c}\text { Germitest }{ }^{(\text {Witness) }} \\
\text { ( })\end{array}$ & Sand & Coal & Ground & Brown Paper \\
\hline 9 & $86 \mathrm{~b}$ & $94 \mathrm{a}$ & $95 \mathrm{a}$ & $94 \mathrm{a}$ & $99 \mathrm{a}$ \\
10 & $91 \mathrm{c}$ & $94 \mathrm{bc}$ & $97 \mathrm{a}$ & $94 \mathrm{bc}$ & $99 \mathrm{a}$ \\
11 & $81 \mathrm{~b}$ & $90 \mathrm{~b}$ & $97 \mathrm{a}$ & $95 \mathrm{ab}$ & $98 \mathrm{a}$ \\
12 & $88 \mathrm{~b}$ & $89 \mathrm{~b}$ & $98 \mathrm{a}$ & $97 \mathrm{a}$ & $97 \mathrm{a}$ \\
13 & $91 \mathrm{~b}$ & $98 \mathrm{a}$ & $99 \mathrm{a}$ & $99 \mathrm{a}$ & $99 \mathrm{a}$ \\
\hline \hline
\end{tabular}

Means followed by the same letter in the column do not differ statistically from each other by the Tukey test for the substrates used at $5 \%$ probability. Source: Authors.

The use of different substrates such as germitest $₫+$ sand; germitest ${ }^{\circ}+$ coal; germitest $₫$ + soil and brown paper, have great influence, because according to the type of material used, factors such as structure, aeration, water holding capacity and degree of pathogen infestation, can vary from one to the other. Thus, there may be differences between the results, if there is no standardization of the methodology with respect to the substrate, taking into account the presence of some chemical treatment.

When observing the interaction of substrates with chemical treatments and temperatures for the hybrid Morgan 30A37PW (tables 3 and 4), all substrates used had a positive effect on seed germination, exceeding $85 \%$ of germination, which are included in the percentage minimum germination made official by the Brazilian State Seeds and Seedling Commissions.

Regarding the relationship between the substrates for the hybrid FS 533PWV (tables 5 and 6), treatment 10 (Inside FS) applied to the substrate germitest ${ }^{\circledR}+$ sand under the temperature of $25^{\circ} \mathrm{C}$ obtained a germination potential below the minimum required for commercialization of seeds. A greater presence of abnormal seedlings was also observed for this treatment.

This fact may have occurred through the high dosage of the chemical treatment together with the constant temperature for high germination and the smaller seed size of the hybrid, thus generating a phytotoxic effect of the treatment even with the addition of sand on the seeds. Among all the tested substrates, charcoal was the one that showed the best performance 
regarding the initial seedling development for both tested hybrids, treatments and temperatures, and a single count can be performed at 4 days after the germination test assembly. This is because mineral coal is a by-product rich in potassium.

Potassium, unlike nitrogen and phosphorus, does not enter the formation of any organic compounds in the plant. Its main function is linked to the metabolism of the plant and because of this it allows the plants to develop faster. Potassium is not part of organic compounds, nor does it have a structural function in the plant, but it acts on the activation of approximately 50 enzymes, especially syntheses, oxireductases, dehydrogenases, transferases, kinases, aldolases and rubisco, a key enzyme in the photosynthetic process. It is also involved in protein synthesis, so that in plants with low potassium levels, there is a reduction in this synthesis, with accumulation of low molecular weight compounds, such as amino acids, amides, amines and nitrates (Marschner, 2005; Malavolta et al., 2006).

However, there are no references to these substrates in the RAS, only to paper towels and sand, which can be used in the tests (Brasil, 2009). Thus, the use of the charcoal substrate in the germination test should be studied, as the humidity of the substrate varies depending on the conditions of the environment and the presence of nutrients from the wood positively affect seedling growth (Tobe et al., 2018).

The brown paper substrate also showed high germination performance for the two hybrids tested, reducing the effects of phytotoxicity when the treated seed comes into direct contact with the paper. This substrate helped in the proper development of primary and secondary roots in the species, besides verifying a single test count at 4 days after installation. However, this is a material that is difficult to acquire and has a high cost to purchase, as it is an imported material and peculiarly manufactured for germination tests.

According to Marcos Filho (2007), the results of the germination test are used to compare the physiological quality of lots, determine the sowing rate and serve as a parameter for seed commercialization. For commercial purposes, the adoption of an efficient procedure in the installation, conduction and evaluation of the tests allows to obtain comparable results between laboratories of companies that supply and buy seeds.

Regarding the effect of treatments on seedling emergence, for the Morgan 30A37 PW and FS 533PWV hybrids as observed in Tables 7 and 8, no significant differences were observed between chemical treatments. It happened that in treated seeds the vigor test was better than the germination test, with ideal conditions for the development of the species under study. This may have occurred due to the seed treatment becoming phytotoxic to the seeds, due to the smaller contact area of the germitest ${ }^{\circledR}$ paper compared to the field emergency.

This was verified by Kobori (2011), in the germination test in treated castor seeds, and some fungicide treatments caused a reduction in the physiological potential in the germitest ${ }^{\circledR}$ paper, however, this phytotoxicity effect was not observed in the emergency test of seedlings in the field.

When it comes to the use of substrates for emergencies, the hybrid Morgan 30A37PW (Table 7) showed lower performance on the sand substrate for all treatments. Being indicated for this hybrid the use of soil substrate in tray, thus allowing the seedlings when emerged to have the presence of a well-developed primary and secondary root and with no phytotoxicity when TSI is performed. 
Table 7: Result of the emergency test of the Morgan Hybrid 30A37PWV on different substrates: soil and sand, under different chemical treatments: treatment 1 (control), treatment 2 (Inside FS), treatment 3 (Inside FS + Maestro FS), treatment 4 (Maestro FS), treatment 5 (Poncho), treatment 6 (Inside FS + BioCoat Corn), treatment 7 (Inside FS + 0Maestro FS + BioCoat Corn), treatment 8 (Maestro FS + BioCoat Corn). FAEM/UFPel. Capão do Leão, RS, 2020.

\begin{tabular}{ccc}
\hline \hline \multirow{2}{*}{ TREATMENTS } & \multicolumn{2}{c}{ SUBSTRATES } \\
\cline { 2 - 3 } & Ground & Sand \\
\hline \hline 2 & $97 \mathrm{a}$ & $78 \mathrm{ab}$ \\
3 & $93 \mathrm{a}$ & $79 \mathrm{ab}$ \\
4 & $96 \mathrm{a}$ & $73 \mathrm{~b}$ \\
5 & $97 \mathrm{a}$ & $75 \mathrm{~b}$ \\
6 & $94 \mathrm{a}$ & $72 \mathrm{~b}$ \\
7 & $97 \mathrm{a}$ & $83 \mathrm{ab}$ \\
8 & $93 \mathrm{a}$ & $83 \mathrm{ab}$ \\
& $90 \mathrm{a}$ & $89 \mathrm{a}$ \\
\hline \hline
\end{tabular}

\section{CV $(\%) 6,8$}

Means followed by the same letter in the column do not differ statistically from each other by the Tukey test for the substrates used at $5 \%$ probability.

Source: Authors.

Table 8: Result of the emergency test of the Hybrid FS 533PWV on different substrates: soil and sand, under different chemical treatments: treatment 9 (witness), treatment 10 (Inside FS), treatment 11 (Inside FS + Maestro FS), treatment 12 (FS conductor), treatment 13 (Poncho). FAEM/UFPel. Capão do Leão, RS, 2020.

\begin{tabular}{ccc}
\hline \multirow{2}{*}{ TREATMENTS } & \multicolumn{2}{c}{ SUBSTRATES } \\
\cline { 2 - 3 } & Ground & Sand \\
\hline \hline 9 & $95 \mathrm{a}$ & $98 \mathrm{a}$ \\
10 & $96 \mathrm{a}$ & $98 \mathrm{a}$ \\
11 & $87 \mathrm{a}$ & $99 \mathrm{a}$ \\
12 & $93 \mathrm{a}$ & $100 \mathrm{a}$ \\
13 & $87 \mathrm{a}$ & $100 \mathrm{a}$ \\
\hline \hline
\end{tabular}

\section{CV (\%) 1,5}

Means followed by the same letter in the column do not differ statistically from each other by the Tukey test for the substrates used at $5 \%$ probability.

Source: Authors.

For the hybrid FS 533PWV, the soil and sand substrates tested separately (table 8) for tray emergence showed high performance of the emerged seedlings, with no phytotoxicity nor the presence of seedling abnormalities.

As stated by Figliolia (2013), the performance of seed analyzes is of paramount importance as it provides information that expresses its physical and physiological quality, and this information can be used for sowing and storage purposes. 


\section{Conclusion}

The most suitable substrates for installing the chemically treated corn germination test were brown pepper and germitest ${ }^{\circledR}+$ charcoal.

Brown paper was the substrate that best presented germinative potential regardless of temperature and chemical treatment carried out. However, it is the substrate that presents the highest financial cost for its acquisition. Germitest ${ }^{\circledR}+$ charcoal substrate, on the other hand, showed the best performance regarding the initial seedling development for the two hybrids tested, and a single count can be performed at 4 days after the germination test assembly.

The temperature of $20^{\circ} \mathrm{C}$ allows the more uniform and rapid development of normal seedlings in the germination test in treated hybrid corn seeds. As for the seeds coated with polymer, it can be seen that it has the potential to interfere in the phytotoxicity of insecticides.

\section{Acknowledgments}

The authors would like to thank Coordenação de Aperfeiçoamento de Pessoal de Nível Superior (CAPES).

\section{References}

Artuzo, F. D., Foguesatto, C. R., Souza, A. R. L., \& Silva, L. X (2018). Cost management in the production of corn and soybeans. Brazilian Journal of Business Management, 2(2), 273-294.

Bail, J. L. Relationships between seed treatment, physiological and health parameters and seed conservation. F. State University of Ponta Grossa. (2017). $B A S F$. Package insert for Poncho® Insecticide.

Brasil. Ministry of Agriculture, Livestock and Supply (2009). Rules for seed analysis. Map/ACS.

Brasil, Ministry of Agriculture and Agrarian Reform (1992). Rules for seed analysis. SNDA / DNDV / CLAV. 365p.

Carvalho, N. M., Nakagawa (2000), J. Seeds: science, technology and production. FUNEP. 588 p.

Castro, P. R. C., Serciloto, C. M., Pereira, M. A., Rodrigues, J. L. M., \& Rossi, G. (2006). Agrochemicals for hormonal control, phosphites and potential application of amino acids in tropical agriculture. Piracicaba: Rural Producer Series, ESALQ-DIBD. 83p.

Castro, G. S. A., Bogiani, J. C., Silva, M. G., Gazola, E., \& Rosolem, C. A. (2018). Treatment of soybean and corn seeds with insecticides and a biostimulant. Brazilian agricultural research, 43(10), 1311-1318.

Conab (2020a). National Supply Company. Historical series of harvests.

Conab (2020b). National Supply Company. Grain harvest bulletin.

GrowCrops (2016). Effective Management. Pellets - Large Cultures. Edition 277. 45p.

Costa, C. J., Villela, F. A., Bertoncello, M. R., Tillmann, M. A. A., \& Menezes, N. L. (2008). Pre-hydration of pea seeds and their interference in the assessment of physiological potential. Brazilian Seed Magazine, 30(1),.198-207.

Figliolia, M. B., Oliveira, E. C., \& Piña-Rodrigues, F. C. M. (2013). Seed analysis. Seeds. ABRATES. 137-174.

Gallo, D., Nakano, O., \& Silveira Neto, S. (2018). Manual of agricultural entomology. (5a ed.), CERES.449 p.

Guan, Y., Hu, J., Wang, X., \& Shao, C. (2019). Seed priming with chitosan improves maize germination and seedling growth in relation to physiological changes under low temperature stress. Seed Science Center, Crosschecked, 15(10), 427-433.

Hall, A. E. (2016). Heat Stress and its impact. Crop Response to Environment, CRC Press.

International seed testing association. (2004). Germination. In: ISTA. International Rules for Seed Testing. Bassersdorf: ISTA. p.5.1- 5.5, 5A.1- 5A.50.

Machado, A. A., \& Conceição, A. R. (2005). WinStat - Statistical Analysis System for Windows. Beta version. Federal University of Pelotas.

Machado, J.C. (1988). Seed pathology: fundamentals and applications. MEC, ESALQ/FAEPE, Lavras, p.107.

Malavolta, E. (2006). Plant nutrition manual. Agronômica Ceres. 631p.

Marcos F. J. (2005). Physiology of seeds of cultivated plants. Fealq. 495p. 
Research, Society and Development, v. 10, n. 13, e551101321457, 2021

(CC BY 4.0) | ISSN 2525-3409 | DOI: http://dx.doi.org/10.33448/rsd-v10i13.21457

Marcos F. J., Cicero, S. M., \& Silva, W. R. (2007). Seed quality assessment. FEALQ. 230 p.

Marschner, H. (2005). Mineral nutrition of higher plants. (2a ed.), Academic. 889p.

Maude, R. (2008). Progress in seed treatment. In: Panamerican Seminar Of Semillas, 25. 99-106.

Menten, J. O., \& Moraes, M. H. D. (2015). Seed treatment: history, types, characteristics and benefits. ABRATES Newsletter, $20(3), 52-53$.

Miranda, R. A. (2018). A civilization success story. The Farm, 74(829), 24-27.

Nascimento, W. M. (2018). Temperature X germination. Seed News, 4(6), 44-45.

Nerson, H. (2017). Seed production and germinability of cucurbit crops. Seed Science Biotechnology, 1(1), 1-10.

Nunes, J. R. G., Menezes, N. L., \& Cargnelutti F, A. (2019). Physiological quality of silage sorghum seeds submitted to different processing sequences. Agricultural Research Gaúcha, 15(1), 21-28.

Phaneendranath, B.R. (2000). Influence of amount of water in the paper towel on standard germination tests. Journal of Seed Technology, 5(2), 82-87.

Parera, C. A., \& Cantliffe, D. J. (2014). Presowing seed priming. Horticultural Reviews, 20(6), 109-141.

Pollock, B. M. (2004). Effect of environment after sowing on viability. In: ROBERTS, E.H. (Ed.) Viability of seeds. London: Chapman and Hall. 150-171.

Sampaio, N. V., \& Sampaio, T. G. (2008). Seeds: with the colors of efficiency. A Granja Magazine, 12, 16-18.

Sans, L. M. A., \& Santana, D. P. (2018). Cultivation of corn: climate and soil. Sete Lagoas: EMBRAPA Milho e Sorgo.

Simoni, F., Costa, R. S., Fogaça, C. A., \& Gerolineto, E. (2015). Seeds of Sorghum bicolor L. - Gramineae, submitted to water stress simulated with PEG (6000). Journal of Biology and Earth Science, 11(1), 188-192.

Silva, B. E. C., \& Silva, M. R. J. (2017). Economic and financial feasibility of implanting corn in the municipality of Santa Teresa-ES. Univap Magazine, 23(43), 17-25.

Silveira, S. (2010). Covering as a measure to protect the seed. Seed News, 5, 34-35.

Smith, S. (2011). Colorants and polymers: there is a difference. Seed World, 200(13), 26-27.

Tobe, K., Zhang, L., \& Omasa, K. (2018). Seed germination and seedling emergence of three annuals growing on desert sand dunes in China. Annals of botany, 200(14), 649-659.

Uneme, H. (2011). Chemistry of Clothianidin and Related Compounds. Journal of Agricultural and Food Chemistry, 59, $2932-2937$.

United States Department of Agriculture. (2020). Grain: world markets and trade. 